\title{
Comparative analysis of cadmium uptake and distribution in contrasting canadian flax cultivars
}

Megan A. House $1^{*} \mathbb{D}$, Lester W. Young ${ }^{1}$, Xia Liu² ${ }^{2}$ Karsten Liber ${ }^{2}$, Axel Diederichsen $^{3}$ and Helen M. Booker ${ }^{4^{*}}$

\begin{abstract}
Objective: Humans consume low quantities of cadmium (Cd), a non-nutritive and potentially toxic heavy metal, primarily via the dietary intake of grains. A trial experiment was conducted to investigate physiological and developmental differences in Cd content in four flax cultivars ('AC Emerson', 'Flanders,' $C D C$ Bethune', and 'AC McDuff') as part of a study to provide information that will assist in the breeding of low Cd-accumulating flax cultivars. Our objective was to identify varietal differences in the uptake and distribution of $\mathrm{Cd}$ in various tissues among flax cultivars grown in naturally $\mathrm{Cd}$-containing soil in a controlled environment.

Results: Cadmium concentration was dependent on genotype, developmental stage, and tissue type, as well as their interaction. Cadmium concentration was higher in roots and leaves, relative to all other tissues, with a general trend of decreasing Cd content over time within leaves and stems. Notably, the concentration of Cd was higher in 'AC Emerson' relative to 'AC McDuff' across tissues and ages, including the seeds, while the concentration of 'Flanders' was higher than in 'AC McDuff' in seeds and other reproductive organs but similar in roots and leaves. The results suggest varietal differences in the mechanisms that determine $\mathrm{Cd}$ content in seeds.
\end{abstract}

Keywords: Flax, Breeding, Cadmium, Heavy metal, Development, Uptake, Translocation

\section{Introduction}

Cadmium (Cd), a heavy, non-nutritive, and potentially toxic metal, is found naturally in the environment at low levels, although anthropogenic activities have resulted in substantially higher levels in the soil [1]. Soil-borne Cd is not a direct concern for human health, however, foodborne $\mathrm{Cd}$ is the major route of exposure for most people [2]. Cadmium is readily taken up by plants through their roots and some crops may accumulate high levels of $\mathrm{Cd}$ in their seeds $[3,4]$.

\footnotetext{
*Correspondence: megan.house@usask.ca; hbooker@uoguelph.ca 1 Department of Plant Sciences, University of Saskatchewan, 51 Campus Drive, Saskatoon, SK S7N 5A8, Canada

${ }^{4}$ Department of Plant Agriculture, Ontario Agricultural College, University of Guelph, 50 Stone Rd E, Guelph, ON N1G 2W1, Canada

Full list of author information is available at the end of the article
}

There are currently no recommendations for acceptable levels of $\mathrm{Cd}$ in flaxseed, however, the recommended weekly maximum dietary intake set out by the European Food Safety Authority is $2.5 \mu \mathrm{g}$ of Cd per $\mathrm{kg}$ of body weight [5]. The concentration of $\mathrm{Cd}$ in flaxseed may influence food processor and consumer choices, particularly in the health food sector. To improve marketability and healthfulness of Canadian flaxseed, breeding of Canadian flax cultivars will include selection for low Cd-accumulating genotypes.

The efficiency with which Cd uptake occurs, and where it is distributed and accumulated within plants, is determined partially by genetics [4, 6-9]. Variety-specific differences in the concentration of $\mathrm{Cd}$ accumulated in flax seeds have been studied but these studies did not investigate differences in uptake and translocation [1013]. Identifying developmental and/or tissue-specific

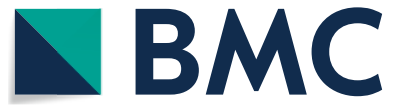

(c) The Author(s) 2020. This article is licensed under a Creative Commons Attribution 4.0 International License, which permits use, sharing, adaptation, distribution and reproduction in any medium or format, as long as you give appropriate credit to the original author(s) and the source, provide a link to the Creative Commons licence, and indicate if changes were made. The images or other third party material in this article are included in the article's Creative Commons licence, unless indicated otherwise in a credit line to the material. If material is not included in the article's Creative Commons licence and your intended use is not permitted by statutory regulation or exceeds the permitted use, you will need to obtain permission directly from the copyright holder. To view a copy of this licence, visit http://creativeco mmons.org/licenses/by/4.0/. The Creative Commons Public Domain Dedication waiver (http://creativecommons.org/publicdomain/ zero/1.0/) applies to the data made available in this article, unless otherwise stated in a credit line to the data. 
differences in $\mathrm{Cd}$ concentration will increase our understanding of genetic factors associated with low-Cd flaxseed and allow for more strategic and accelerated breeding approaches.

This experiment was performed as part of a larger investigation of seed $\mathrm{Cd}$ concentrations in different flax germplasm resources for the purposes of breeding low$\mathrm{Cd}$ accumulating cultivars. This study investigates the genotypic differences in $\mathrm{Cd}$ concentration between vegetative tissues and reproductive structures throughout development. The results of this investigation will be used for designing experiments to identify genes that regulate $\mathrm{Cd}$ accumulation in flaxseed.

\section{Main text}

\section{Methodology}

Four Canadian flax cultivars were selected for this study: 'CDC Bethune' [14], 'AC Emerson' [15], 'Flanders' [16], and 'AC McDuff' [17]. Seed was from the Crop Development Centre's flax breeding program, where they are used as controls. The materials and corresponding voucher specimens are available at Plant Gene Resources of Canada (Saskatoon, SK, Canada), under the conditions of the Multilateral System for Access and Benefit-sharing of the International Treaty on Plant Genetic Resources for Food and Agriculture. Plants were seeded into 4L pots and grown in a controlled environment growth chamber (see Additional file 1 for details on soil, watering, fertilizing, and pest control).

Four developmental stages were selected for tissue collection based on morphological markers (first bud stage, first flower stage, full flowering stage and maturity) (Additional file 1). Tissues were collected (roots, stems, leaves, shoot tips, flowers, immature bolls, and seeds) at all appropriate stages, and were stored at $-80{ }^{\circ} \mathrm{C}$. Tissues were freeze-dried and ground into a powder using a $2010 \mathrm{Geno/grinder} \mathrm{(SPEX} \mathrm{CertiPrep,} \mathrm{Inc.,} \mathrm{Methucen,}$ NJ). Ground, freeze-dried tissue samples were processed at the Toxicology Centre, University of Saskatchewan, before $\mathrm{Cd}$ quantification using inductively coupled plasma-mass spectrometry (ICP-MS).

All statistical analyses were performed in RStudio, version 3.6.3 [18]. Prior to performing analyses of variance (ANOVA), we confirmed the data had equal variance and was normally distributed. Two-way ANOVA was used to test the effects of genotype and tissue on Cd accumulation in reproductive structures using the core $\mathrm{R}$ stats package function, aov() [18]. A three-way mixed ANOVA was performed using the rstatix package [19] function, anova_test(), to test the effects of genotype, age, tissue on $\mathrm{Cd}$ accumulation in vegetative tissues, followed by simple two-way ANOVA when appropriate. Tukey's HSD was used to make pairwise comparisons and the level of significance accepted for all tests was $\mathrm{p}<0.05$.

Additional details on the materials and methods used are in Additional file 1.

\section{Results \\ Accumulation of Cd in flowers, immature bolls and seeds}

Using a two-way ANOVA we determined that genotype and tissue stably affect $\mathrm{Cd}$ concentration within reproductive structures (Additional file 2: Table S1). Specifically, seeds had a higher concentration of $\mathrm{Cd}$ than flowers and immature bolls, and there was no difference between flowers and bolls (Fig. 1). The differences in Cd concentration between seeds and flowers, and seeds and bolls, were stable, with the concentration in 'AC McDuff' lower than that in 'AC Emerson' and 'Flanders', but the same as that in 'CDC Bethune' (Fig. 1).

\section{Genotype, tissue and developmental stage interact to determine $C d$ concentration in flax}

$\mathrm{Cd}$ concentration was measured in roots, stems, leaves and shoot tips in the four flax cultivars at various stages of development. The three-way interaction among genotype, tissue, and age was significant $\left(\mathrm{F}_{9,48}=4.383\right.$, $\mathrm{p}<0.001$ ), so statistical differences within tissues and ages were tested to understand the relationship between genotype and age, and genotype and tissue.

\section{Effect of genotype and age on Cd concentration in roots, stems, leaves and shoot tips}

Within leaves and shoot tips, Cd concentration was stably affected by genotype (Fig. 2; Additional file 2: Table S2, Additional file 3). The concentration of $\mathrm{Cd}$ in leaves was similar in 'CDC Bethune', 'Flanders' and 'AC McDuff' (mean of $5.27 \pm 0.10 \mathrm{mg} / \mathrm{kg}$ ), and was significantly lower than in 'AC Emerson' ( $7.18 \pm 0.29 \mathrm{mg} / \mathrm{kg})$. The level of Cd in shoot tips between 'AC Emerson' and 'Flanders' was

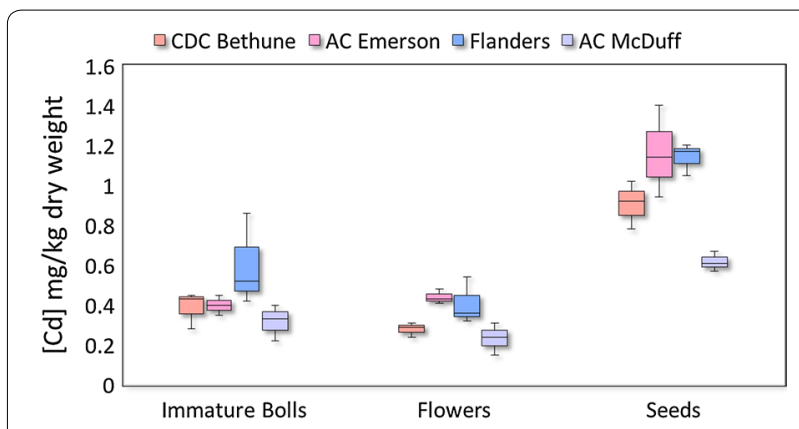

Fig. 1 Boxplot diagram of $\mathrm{Cd}$ concentration in flax reproductive structures. Boxes represent the average $\mathrm{Cd}$ concentration of three replicates for each genotype/tissue combination 

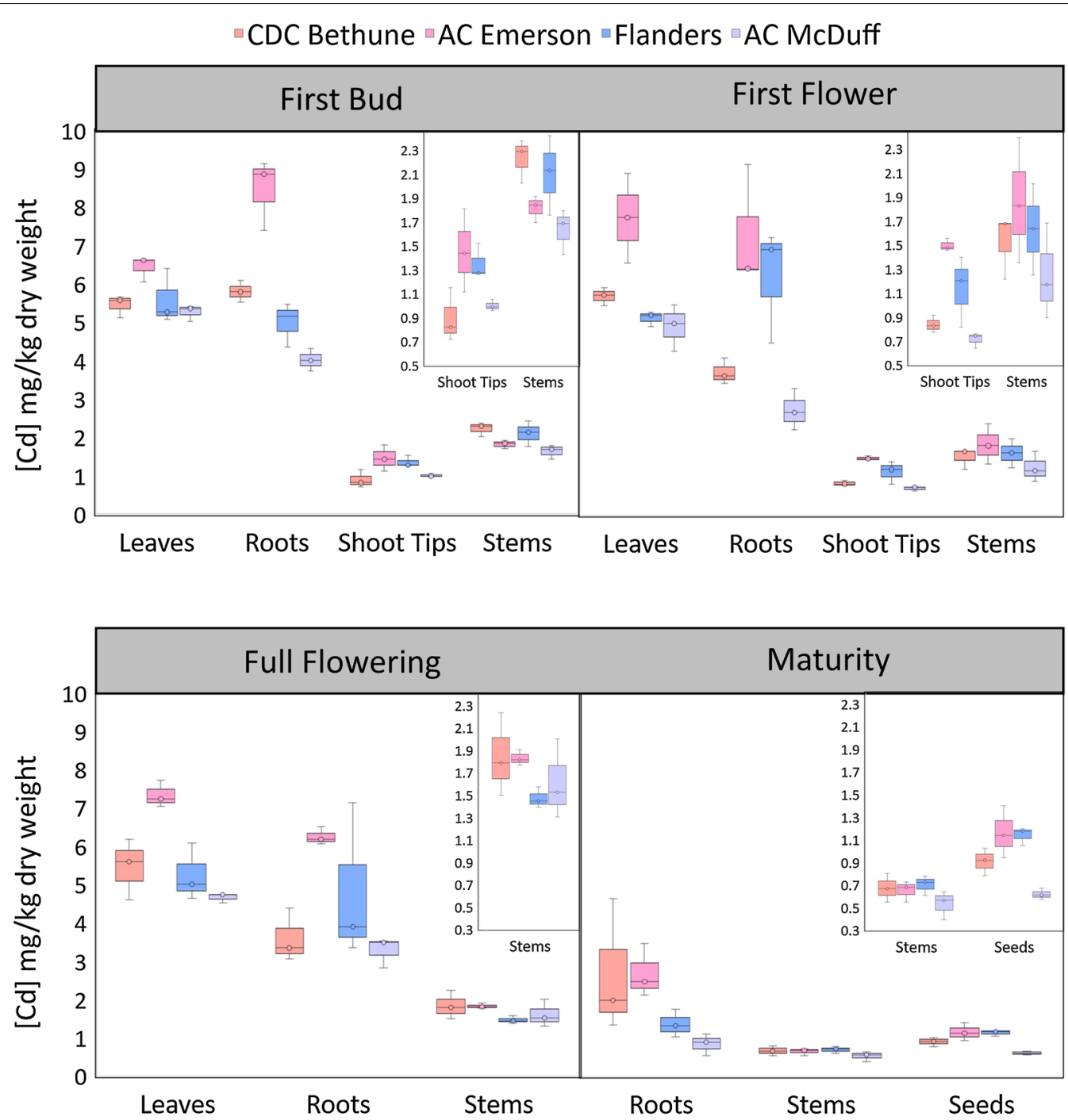

Fig. 2 Boxplot diagram of $\mathrm{Cd}$ concentration in vegetative tissues throughout development. Boxes represent the average $\mathrm{Cd}$ concentration of three replicates for each genotype/tissue combination for the first bud, first flower, full flowering, and maturity stages of development

similar, and both were higher than in 'CDC Bethune' and 'AC McDuff'.

In stems, stable effects of both genotype and age on $\mathrm{Cd}$ concentration were observed, though the effect of genotype was less significant (Additional file 2: Table S2, Additional file 3). Concentrations ranged from 0.39 to $2.42 \mathrm{mg} / \mathrm{kg}$ and the effect of genotype was driven by a difference between 'AC McDuff' $(1.26 \pm 0.15)$ and 'CDC Bethune' (1.57 \pm 0.18 ) (Fig. 2; Additional file 3). Similarly, in stems of all genotypes, there was an overall pattern of decreasing $\mathrm{Cd}$ concentration with increasing age.

Within roots, there was a significant genotype-byage interaction (Fig. 2; Additional file 2: Table S2,
Additional file 3). The developmental pattern of $\mathrm{Cd}$ concentration was similar in 'AC Emerson' and 'Flanders', and in 'CDC Bethune' and 'AC McDuff'. 'AC Emerson' and 'Flanders' exhibited stable $\mathrm{Cd}$ concentrations through the first three stages of development, which declined significantly at maturity. Roots of 'CDC Bethune' and 'AC McDuff', however, had a higher concentration of $\mathrm{Cd}$ at the first developmental stage compared to maturity, but showed no differences among the first flower stage, full flowering stage, and at maturity (Fig. 2; Additional file 3). Genotypic differences were not observed in roots at maturity, however, most interesting is the consistently higher $\mathrm{Cd}$ concentration 
in 'AC Emerson' compared to 'AC McDuff' during all stages of active growth.

\section{Effect of genotype and tissue on Cd concentration through development}

Within developmental stages, the effects of genotype, tissue, and the genotype-by-tissue interaction were compared using a two-way mixed ANOVA. Differences between tissues were dependent on genotype during the first three stages of development only. At maturity, only roots and stems were collected, with roots having a stably higher $\mathrm{Cd}$ concentration than stems (Fig. 2; Additional file 2: Table S3). Notably, the concentration of Cd in leaves was consistently higher than that in stems and shoot tips for all genotypes. The concentration in roots and leaves were similar, but some genotype-specific differences were observed at the first three developmental stages (Fig. 2).

\section{Discussion}

In Canada, flax is grown predominantly in the Prairie province of Saskatchewan, but also in Alberta and Manitoba [20]. Cd concentrations in Saskatchewan soils from the AP soil horizon (that is, in the upper layer soil that has been disrupted by human activity) range from $0.127 \mathrm{mg} / \mathrm{kg}$ to $0.456 \mathrm{mg} / \mathrm{kg}$, with an average concentration of $0.32 \mathrm{mg} / \mathrm{kg}$ [21]. In other parts of the Prairies, soils contain anywhere from $0.1-7.9 \mathrm{mg} / \mathrm{kg}$ of $\mathrm{Cd}$, but the vast majority contain less than the worldwide average of $0.53 \mathrm{mg} / \mathrm{kg}$ [22]. The soil used in our study contained $\sim 0.45 \mathrm{mg} / \mathrm{kg}$ of $\mathrm{Cd}$ and can therefore be considered representative of most agricultural sites in the Canadian Prairies.

As expected, genotype has a significant effect on $\mathrm{Cd}$ concentration in reproductive structures and we determined 'AC Emerson' and 'Flanders' are consistently higher accumulators than 'AC McDuff'. A previous study also found that 'Flanders' accumulates more $\mathrm{Cd}$ in its seeds than 'AC McDuff' [13], and our study indicates this relationship is not restricted to the seed. In addition, we found that the concentration of $\mathrm{Cd}$ is higher in the seeds than in flowers and immature bolls, which indicates that a substantial proportion of seed $\mathrm{Cd}$ is specifically redistributed to the seeds during the seed-filling stage.

The $\mathrm{Cd}$ concentration in seed in our study ranged from $0.57 \mathrm{mg} / \mathrm{kg}$ in 'AC McDuff' to $1.40 \mathrm{mg} / \mathrm{kg}$ in 'AC Emerson'. A quick calculation shows that, even using the lowest accumulator included in this study, it would not be difficult to exceed the weekly-recommended $2.5 \mu \mathrm{g} \mathrm{Cd}$ per $\mathrm{kg}$ of body weight per week after consuming flaxseed. For example, according to this recommendation, a person weighing $60 \mathrm{~kg}(\sim 132 \mathrm{lbs})$ should consume $<150 \mu \mathrm{g}$ of $\mathrm{Cd} /$ week. The health claim for whole flaxseed states that the daily amount of ground flax seed to reduce cholesterol is $40 \mathrm{~g}(0.28 \mathrm{~kg} /$ week $)$ [23]. If the seed contains $0.57 \mathrm{mg} / \mathrm{kg}$ (i.e. the concentration in 'AC McDuff'), an individual following the health claim could be inadvertently ingesting $160 \mu \mathrm{g}$ of $\mathrm{Cd}$ per week from flaxseed alone. This rough calculation puts into perspective the need to effectively and efficiently breed low $\mathrm{Cd}$-accumulating cultivars.

The high level of $\mathrm{Cd}$ in 'AC Emerson' relative to 'AC McDuff' was consistent in most tissues. Had these two cultivars been compared in isolation, one would likely conclude that in flax the differences in seed Cd accumulation are due solely to initial differences in Cd uptake by the roots. While initial differences in $\mathrm{Cd}$ uptake by the roots appear to contribute to varietal differences, the story is more complicated when additional varieties are considered. 'Flanders', for example, also contained more $\mathrm{Cd}$ in its seeds than 'AC McDuff', but approximately the same concentration in roots and leaves. This is an important finding because it indicates that the concentration of $\mathrm{Cd}$ in seeds may also occur because of genotypic differences in the redistribution of $\mathrm{Cd}$ to the seeds during maturity, rather than solely from initial differences in $\mathrm{Cd}$ uptake.

It is important to note that 'AC Emerson' may represent a special case of high $\mathrm{Cd}$ accumulation since it is also tolerant to iron-deficiency chlorosis [15]. Iron transporters in rice and Arabidopsis have been reported to also transport Cd [24-26]. NRAMP1, specifically, is more highly expressed when plants are growing in iron-depleted soils [25]. Greater iron-use efficiency in 'AC Emerson' under low iron conditions could result in a concordant increase in Cd uptake. The consistently high levels of Cd observed in 'AC Emerson' may represent a unique difference in abundance and/or expression of root iron transporters. Mobilization and transport of $\mathrm{Cd}$ during reproductive development may be similar in 'AC Emerson' compared to the other varieties and it may be more typical that the genotypic differences in seed $\mathrm{Cd}$ accumulation are due to differences in redistribution of $\mathrm{Cd}$ from aerial tissues to the seeds.

\section{Conclusion}

Overall, results of our study suggest that genotypic differences in $\mathrm{Cd}$ accumulation in flax seeds may be partly due to differences in the redistribution of $\mathrm{Cd}$ to the seeds during maturation. In the case of chlorosis-tolerant 'AC Emerson', greater initial $\mathrm{Cd}$ uptake may contribute to differences in seed $\mathrm{Cd}$ levels. These results will be useful for future projects aimed at understanding the molecular mechanisms that determine varietal differences in the accumulation of $\mathrm{Cd}$ in flax seed. 


\section{Limitations}

This study had one main limitation. Health and safety requirements for available growth facilities prohibited the application of $\mathrm{Cd}$ to soil or any other media. We were able to use $\mathrm{Cd}$-containing soil collected from a field site but were unable to include a $\mathrm{Cd}$-free control. This limited our study because we were unable to determine if the Cd taken up by plants had an effect on their growth or if the varietal differences in $\mathrm{Cd}$ concentration within tissues and over ages are affected by the original soil Cd concentration.

\section{Supplementary information}

Supplementary information accompanies this paper at https://doi. org/10.1186/s13104-020-05265-1.

Additional file 1. Additional details pertaining to materials and methods for soil preparation, seeding and growth conditions, watering, tissue collection, $\mathrm{Cd}$ quantification and statistical analyses.

Additional file 2: Tables S1-S3. Results of the 1) two-way ANOVA to assess the effect of genotype, tissue, and the genotype-by-tissue interaction on Cd concentration in reproductive structures, 2) two-way ANOVA to assess the effect of genotype, age, and the genotype-by-age interaction in Cd concentration within vegetative tissues, and 3) two-way mixed ANOVA to assess the effect of genotype, tissue, and the genotype-bytissue interaction on $\mathrm{Cd}$ concentration within developmental stages.

Additional file 3: Figure S1. Boxplot diagram presenting Cd concentration (mg/kg dry weight) for each cultivar expressed specifically within vegetative tissues.

\section{Abbreviations}

ANOVA: Analysis of Variance; Cd: Cadmium; SK: Saskatchewan.

\section{Acknowledgements}

The authors would like to acknowledge the technical assistance of Shannon Froese who assisted with plant culture and Claire Owen who collected root tissue samples.

\section{Authors' contributions}

$A D, L Y, H M B \& K L$ conceived experiments. MAH and $L Y$ designed the study and collected data. MAH analyzed the data and was the major contributor to the writing of the manuscript. LWY and $\mathrm{HMB}$ were major contributors to writing of the manuscript and $A D, L W Y$, and $H M B$ were major contributors to the editing and proofreading of the manuscript. $\mathrm{XL}$ analyzed the samples for $\mathrm{Cd}$ content at the Toxicology Centre. All authors have read and approved the final version of the manuscript.

\section{Funding}

This study was part of the Diverse Field Crop Cluster funded under the Canadian Agriculture Program by Agriculture and Agri-Food Canada and the Saskatchewan Flax Development Commission. Agriculture and Agri-Food Canada and the Saskatchewan Flax Development Commission had no role in the design of the study, the writing of the manuscript, nor the collection, analysis, and interpretation of the data.

\section{Availability of data and materials}

The datasets used and/or analysed during the current study are available from the corresponding author on reasonable request.

\section{Ethics approval and consent to participate}

Not applicable

\section{Consent for publication}

All authors have consented to the publication of this manuscript.

\section{Competing interests}

The authors declare that they have no competing interests.

\section{Author details}

${ }^{1}$ Department of Plant Sciences, University of Saskatchewan, 51 Campus Drive, Saskatoon, SK S7N 5A8, Canada. ${ }^{2}$ Toxicology Centre, University of Saskatchewan, Saskatoon, SK, Canada. ${ }^{3}$ Saskatoon Research and Development Centre, Plant Gene Resources of Canada, Agriculture and Agri-Food Canada, 107 Science Place, Saskatoon, SK S7N 0X2, Canada. ${ }^{4}$ Department of Plant Agriculture, Ontario Agricultural College, University of Guelph, 50 Stone Rd E, Guelph, ON N1G 2W1, Canada.

Received: 8 July 2020 Accepted: 1 September 2020

Published online: 07 September 2020

\section{References}

1. di Toppi L, Gabbrielli R. Response to cadmium in higher plants. Environ Exp Bot. 1999;41(2):105-30.

2. WHO. Cadmium: environmental aspects. Environ Health Criteria 135. 1992;156.

3. Yan Y-F, Choi D-H, Kim D-S, Lee B-W. Genotypic variation of cadmium accumulation and distribution in rice. J Crop Sci Biotechnol. 2010;13(2):69-73.

4. LiY, Chaney RL, Schneiter AA, Miller JF. Genotype variation in kernel cadmium concentration in sunflower germplasm under varying soil conditions. Crop Sci. 1995;35(1):137-41.

5. EFSA Panel on Contaminants in the Food Chain (CONTAM). Statement on tolerable weekly intake for cadmium. EFSA J. 2011;9(2):1975.

6. Clemens S, Aarts MGM, Thomine S, Verbruggen N. Plant science: the key to preventing slow cadmium poisoning. Trends Plant Sci. 2013;18(2):92-9.

7. Oliver DP, Gartrell J, Tiller K, Correll R, Cozens G, Youngberg B. Differential responses of Australian wheat cultivars to cadmium concentration in wheat grain. Aust J Agric Res. 1995:46(5):873-86.

8. Hongjiang Z, Xizhou Z, Tingxuan L, Fu H. Variation of cadmium uptake, translocation among rice lines and detecting for potential cadmium-safe cultivars. Environ Earth Sci. 2014;71(1):277-86.

9. Stolt J, Sneller F, Bryngelsson T, Lundborg T, Schat H. Phytochelatin and cadmium accumulation in wheat. Environ Exp Bot. 2003;49(1):21-8.

10. Li Y-M, Chaney RL, Schneiter AA, Miller JF, Elias EM, Hammond JJ. Screening for low grain cadmium phenotypes in sunflower, durum wheat and flax. Euphytica. 1997;94(1):23-30.

11. Moraghan J. Accumulation of cadmium and selected elements in flax seed grown on a calcareous soil. Plant Soil. 1993;150(1):61-8.

12. Cieśliński G, Van Rees K, Huang P, Kozak L, Rostad H, Knott D. Cadmium uptake and bioaccumulation in selected cultivars of durum wheat and flax as affected by soil type. Plant Soil. 1996;182(1):115-24.

13. Oomah BD, Berekoff B, Li-Chan EC, Mazza G, Kenaschuk EO, Duguid SD. Cadmium-binding protein components of flaxseed: Influence of cultivar and location. Food Chem. 2007;100(1):318-25.

14. Rowland G, Hormis Y, Rashid K. CDC Bethune flax. Can J Plant Sci. 2002;82(1):101-2.

15. Kenaschuk E, Rashid K, Gubbels G. AC Emerson flax. Can J Plant Sci. 1996;76(3):483-5.

16. Rowland G, Bhatty R, Kenaschuk E. Flanders flax. Can J Plant Sci. 1990;70(2):543-4.

17. Kenaschuk E, Rashid K. AC Mcduff Flax. Can J Plant Sci. 1994;74(4):815-6.

18. R: A language and environment for statistical computing. [Internet]. Vienna, Austria: R Foundation for Statistical Computing; 2020. Available from: https://www.R-project.org/

19. Kassambara A. Rstatix: pipe-friendly framework for basic statistical tests. 2019;

20. Statistics Canada. Table 32-10-0359-01 Estimated areas, yield, production, average farm price and total farm value of principal field crops, in metric and imperial units.

21. Krishnamurti G, Huang P, Kozak L, Rostad H, Rees KV. Distribution of cadmium in selected soil profiles of Saskatchewan, Canada: speciation and availability. Can J Soil Sci. 1997;77(4):613-9. 
22. Haluschak P, Eilers R, Mills G, Grift S. Status of selected trace elements in agricultural soils of southern Manitoba. Technical Report 1998-6E Land Resource Unit, Brandon Research Centre ...; 1998.

23. Health Canada. Summary of health canada's assessment of a health claim about ground whole flaxseed and blood cholesterol lowering. 2014

24. Nakanishi H, Ogawa I, Ishimaru Y, Mori S, Nishizawa NK. Iron deficiency enhances cadmium uptake and translocation mediated by the Fe2 + transporters OsIRT1 and OsIRT2 in rice. Soil Sci Plant Nutr. 2006:52(4):464-9.

25. Takahashi R, Ishimaru Y, Nakanishi H, Nishizawa NK. Role of the iron transporter OsNRAMP1 in cadmium uptake and accumulation in rice. Plant Signal Behav. 2011;6(11):1813-6.
26. Thomine S, Wang R, Ward JM, Crawford NM, Schroeder Jl. Cadmium and iron transport by members of a plant metal transporter family in Arabidopsis with homology to Nramp genes. Proc Natl Acad Sci. 2000;97(9):4991-6.

\section{Publisher's Note}

Springer Nature remains neutral with regard to jurisdictional claims in published maps and institutional affiliations.
Ready to submit your research? Choose BMC and benefit from:

- fast, convenient online submission

- thorough peer review by experienced researchers in your field

- rapid publication on acceptance

- support for research data, including large and complex data types

- gold Open Access which fosters wider collaboration and increased citations

- maximum visibility for your research: over $100 \mathrm{M}$ website views per year

At BMC, research is always in progress.

Learn more biomedcentral.com/submissions 